\begin{tabular}{|l|l|l|}
\hline Diserahkan: 24 April 2021 & Diterima: 25 Juli 2021 & Diterbitkan: 10 Oktober 2021 \\
\hline
\end{tabular}

\title{
Model Pembinaan Warga Gereja Bagi Generasi Milenial
}

\author{
Regen Wantalangi; Anly Frinsisca Killa; Juliana; David Eko Setiawan \\ Sekolah Tinggi Teologi Tawangmangu \\ Regen.wantalangi@gmail.com \\ Anlykilla@gmail.com \\ Julianajait40@gmail.com \\ Davidekosetiawan14217@gmail.com
}

\begin{abstract}
This paper aims to find the right model for coaching for millennials. Millennials are known as the generation that participates the most in the late 20th and early 21 st century in the discovery and development of technology and other applied sciences, is also a generation that enjoys working, thinking innovatively and creatively and has a high competitive, open, and flexible sense. The research method used in this study is literature studies. The results of this study show that there needs to be a renewal and relevance of each model of church development for millennials considering millennials are independent generations. Therefore the model of fostering the synthesis of contextual is the most appropriate model for millennials.
\end{abstract}

Key words: Model; Coaching; The Church; Millennial.

\begin{abstract}
Abstrak
Tulisan ini bertujuan untuk menemukan model yang tepat untuk pembinaan bagi generasi milenial. Generasi milenial dikenal sebagai generasi yang berpartisipasi paling banyak di akhir abad 20 dan awal abad 21 dalam penemuan dan pengembangan teknologi dan ilmu terapan lainnya, juga merupakan generasi yang senang bekerja, berfikir inovatif dan kreatif serta memiliki rasa kompetitif yang tinggi, terbuka, dan fleksibel. Metode penelitian yang digunakan dalam penelitian ini adalah studi literatur. Hasil dari penelitian ini menunjukan bahwa perlu adanya pembaharuan dan relevansi dari setiap model pembinaan gereja bagi generasi milenial menimbang generasi milenial adalah generasi yang independen. Oleh karena itu model pembinaan sintesis kontekstual adalah model yang paling tepat bagi generasi milenial.
\end{abstract}

Kata kunci: Model; Pembinaan; Gereja; Milenial. 


\section{PENDAHULUAN}

Matius 28:19-20 merupakan Amanat Agung dari Yesus Kristus. ${ }^{1}$ Disebut Amanat Agung karena dipandang sebagai perintah terakhir Yesus kepada murid-murid sebelum terangkat ke sorga. ${ }^{2}$ Amanat agung secara umum dipahami sebagai tugas dari semua orang Kristen untuk membawa dan menjadi kabar baik bagi dunia. Namun bukan hanya di luar gereja melainkan di dalam gereja juga, amanat agung juga berbicara tentang "ajarlah" yang artinya gereja harus memberi pengajaran kepada warga gereja agar mereka mengerti, memahami, dan, dapat melakukan apa yang Yesus ajarkan. Oleh karena itu, amanat agung juga menekankan pada pembinaan warga gereja. ${ }^{3}$ Dengan dasar Alkitab ini (Mat. 28:19-20), amanat agung dilakukan agar setiap orang mengenal Yesus Kristus ${ }^{4}$ kemudian dibina sehingga mengalami pertumbuhan di dalam pengenalan kepada Yesus Kristus. Karena pembinaan warga gereja merupakan suatu keharusan bagi gereja untuk melakukan proses pendewasaan warga gereja. ${ }^{5}$

Gereja diperhadapkan dengan perkembangan zaman yang begitu pesat terutama pada abad 21 dan modernisasi masih terus berlanjut sampai hari ini. Zaman ini ada banyak penemuan dan pengembangan yang dilakukan dalam bidang teknologi, informasi, dan bidangbidang yang lain sehingga menciptakan suatu kelompok yang disebut masyarakan global. Dengan perkembangan inilah terjalin suatu hubungan yang erat antara satu dengan yang lain. Semua informasi dengan sekejap mata dapat diakses melalui media sosial menjadikan masyarakat berstatus masyarakat global.

Berbicara mengenai perkembangan teknologi dan globalisasi tentunya tidak lepas dari Generasi Milenial. Generasi Milenial atau yang sering disebut generasi Y adalah generasi yang lahir sekitar tahun 80-90an. Generasi Milenial dikenal sebagai generasi yang berpartisipasi paling banyak di akhir abad 20 dan awal abad 21 dalam penemuan dan pengembangan teknologi dan ilmu terapan lainnya. Generasi Milenial merupakan generasi yang senang bekerja, berfikir inovatif dan kreatif serta memiliki rasa kompetitif yang tinggi, terbuka, dan fleksibel.

\footnotetext{
${ }^{1}$ Ruat Diana, "Permasalahan Pembinaan Warga Gereja Di Kewari," Evangelikal: Jurnal Teologi Injili Dan Pembinaan Warga Jemaat 2, No. 1 (2018): 28.

${ }^{2}$ Armand Barus, "Pemuridan Sebagai Misi Gereja Studi Matius 28:16-20," Jurnal Amanat Agung (2013): 1 .

${ }^{3}$ Diana, "Permasalahan Pembinaan Warga Gereja Di Kewari."

${ }^{4}$ Sostenis Nggebu, "Pemuridan Model Epafras Sebagai Upaya Pendewasaan Iman Bagi Warga Gereja," Jurnal Teologi Kristen, Sekolah Tinggi Alkitab Tiranus 3 (2019): 2.

${ }^{5}$ S Susanto, "Strategi Pembinaan Warga Jemaat Dalam Meningkatkan Kehidupan Jemaat (Studi Kasus Di Gkii Tandang)," In Prosiding Seminar Nasional Pendidikan Agama Kristen Dan Call For Papers, $2016,14$. 
Telah ada beberapa kajian yang berkaitan dengan pembinaan warga gereja bagi generasi milenial, seperti penelitian Thobias tentang pembentukan karakter pemimpin Kristen yang unggul di era milenial. ${ }^{6}$ Dan juga Yw Ardhana Septiani Bulo tentang kepemimpinan transformasional dalam gereja bagi pelayanan generasi muda milenial dan z. ${ }^{7}$ Kedua penelitian ini berpusat pada pembentukan dan pengkaderaan pemimpin di era milenial. Selanjutnya penelitian Ezra Tari dkk, tentang kajian biblika motivasi Yudas Iskariot mengikut Yesus berdasarkan Injil Sinoptik dan relevansinya bagi generasi milenial, dimana generasi milenial kerapkali memiliki permasalahan dengan diri sendiri sama seperti Yudas dan hal itulah yang perlu untuk diselesaikan. ${ }^{8}$ Namun demikian untuk penelitian terhadap model pembinaan warga gereja bagi generasi milenial belum banyak diteliti. Hal inilah yang mendorong penulis untuk meneliti dan mencari sumber-sumber data yang berkaitan dengan generasi milenial. Penelitian ini bertujuan memberikan metode dan strategi pembinaan warga gereja khususnya bagi generasi milenial. Usaha ini penting karena gereja perlu mengerti bahwa di dalam gereja terdapat warga jemaat generasi milenial. Gereja mesti mengerti apa yang menjadi kebutuhan dan hal yang menarik bagi generasi milenial. Gereja sebagai wadah mesti menyiapkan model; metode dan strategi untuk menarik minat generasi milenial agar tetap menyeimbangkan kebutuhan rohani dan kebutuhan jasmani mereka. menimbang Indonesia juga sedang menanti puncak keemasan bonus demografi yang didominasi oleh generasi milenial.

\section{METODE PENELITIAN}

Metode yang digunakan adalah studi literatur. Metode ini adalah serangkaian kegiatan yang bersangkutan dengan pengumpulan data pustaka, membaca dan mencatat, dan pengelolaan data penelitian. Tujuan utama metode studi literatur untuk mengembangkan dua aspek yaitu, aspek teoritis, dan aspek praktisi. ${ }^{9}$ Dalam tulisan ini penulis memberi kosentrasi terhadap tujuan metode studi literatur dalam aspek praktisi karena membahas tentang model pembinaan warga gereja. Ada pun pengumpulan data yang diperoleh berasal dari kepustakaan ${ }^{10}$ yang berkaitan dengan objek penelitian.

Dalam penelitian ini juga melibatkan model teologi kontekstualisasi, adapun model yang dipakai adalah model sintesis kontekstual. Model sintesis kontekstual berupaya

${ }^{6}$ Apriati W. S. Thobias, "Pembentukan Karakter Pemimpin Kristen Yang Unggul Di Era Milenial," Kharisma: Jurnal Ilmiah Teologi Vol. 1, No (2020): 69.

${ }^{7}$ Yw Ardhana Septiani Bulo, "Kepemimpinan Transformasional Dalam Gereja Bagi Pelayanan Generasi Muda (Y Dan Z)," Duta Wacaana (N.D.): 2.

${ }^{8}$ Ezra Tari Et Al., "Kajian Biblika Tentang Motivasi Yudas Iskariot Mengikut Yesus Berdasarkan Injil Sinoptik Dan Relevansinya Bagi Generasi Milenial," Osf (2019). 1

${ }^{9}$ Mkes Eka Diah Kartiningrum, Panduan Penyusunan Studi Literatur (Mojokerto: Lembaga Penelitian Dan Pengabdian Masyarakat Politeknik Kesehatan Majapahit Mojokerto, 2015), 5.

${ }^{10}$ Kartini Kartono, Pengantar Metodologi Research Sosial (Bandung: Alumni Bandung, 1980), 78. 
mengembangkan segala sesuatu secara dialetis dan kreatif sehingga dapat juga digunakan terhadap model pembinaan bagi generasi milenial. ${ }^{11}$

\section{HASIL DAN PEMBAHASAN}

\section{Pengertian Pembinaan Warga Gereja}

Untuk setiap pelayanan gerejawi memerlukan pengertian yang benar tentang pengertian pembinaan agar terarah dan sistematis, karena dari pemahaman yang benar juga akan menghasilkan langkah yang benar. Selan, memaparkan bahwa pembinaan adalah suatu usaha yang memperlengkapi anggota jemaat sebagai anggota Tubuh Kristus untuk lebih memahami ajaran Kristus (Ef 4:11-16). ${ }^{12}$ Pembinaan dalam jemaat lokal berfungsi untuk membangun Tubuh Kristus sehingga jemaat boleh mengerti maksud Tuhan. Pembinaan juga sinonim dengan kata memuridkan, dan mendidik, itu berarti pembinaan sama dengan memuridkan dan mendidik. B.S. Sidjabat, memaparkan tiga pengertian pembinaan.

Pertama, istilah pendidikan biasa dipakai dalam pendidikan formal seperti sekolah dan universitas. Sedangkan istilah pembinaan biasa dipakai dalam kegiatan belajar di luar jalur sekolah dan universitas, berkonotasi nonformal. Contohnya dalam gereja sering digunakan istilah ini, namun ada juga yang menggunakan istilah pemuridan, dan pembangunan warga gereja. Ada pun kegiatan pembinaan di gereja berbeda dengan kegiatan yang berlangsung dalam aktivitas pembelajaran yang bersifat formal dan berjenjang. Kedua, pendidikan orang dewasa berarti: praktik pendidikan dari, oleh dan untuk serta bersama orang dewasa, dengan dasar, tujuan dan dinamika yang berlandaskan iman Kristiani. Tujuan hidup dari iman kristiani adalah mempermuliakan Allah Bapa, Putra, dan Allah Roh Kudus, dengan melakukan kehendak Allah Tritunggal dan melakukan kasih terhadap sesama manusia dalam keseluruhan hidup seorang Kristen. Ketiga, pendidikan merupakan kegiatan pengajaran, pelatihan, pembinaan, pendampingan dan pembimbingan. Dengan kata lain, pembinaan adalah bagian dari pendidikan. Dalam pembinaan bisa saja pelajar mengalami perubahan secara kognisi tetapi belum tentu secara afeksi. Maka dari itu kegiatan pembinaan di jemaat sepatutnya bersifat holistik. Artinya aktifitas itu membimbing mereka untuk mengalami perubahan dalam emosi, iman dan kerohanian serta perbuatan nyata. ${ }^{13}$ Dari pandangan di atas, maka jelas pembinaan gereja adalah suatu pelayanan yang serius yang harus dikelola dengan teliti agar tujuan dalam pembinaan gereja dapat tercapai dengan maksimal.

${ }^{11}$ David Eko Setiawan, "Ritus Pencurahan Darah Korban Binatang: Perjumpaan Injil Dengan Tradisi Manengeh Di Suku Dayak Bumate," Caraka, Jurnal Teologi Bliblika Dan Praktika 2 (2021): 4.

12 Ruth F. Selan, Pedoman Pembinaan Warga Jemaat (Bandung: Kalam Hidup, 2000), 13.

${ }^{13}$ B.S. Sidjabat, Pendewasaan Manusia Dewasa (Bandung: Kalam Hidup, 2014), 2. 


\section{Mengenal Generasi Milenial secara Umum}

Dinilai dari segi umur, Generasi Milenial dibagi menjadi dua bagian, yaitu; golongan dewasa produktif (80-an), dan golongan dewasa muda (90-an). Oleh karena itu, pengertian pembinaan yang telah dipaparkan berlaku juga untuk Generasi Milenial. Dikutip dari buku Statistik gender tematik: profil generasi milenial Indonesia 2018. Manheim mengatakan, bahwa generasi adalah suatu konstruksi sosial yang didalamnya terdapat sekelompok orang yang memiliki kesamaan umur dan pengalaman historis yang sama. Individu yang menjadi bagian dari satu generasi adalah mereka yang memiliki kesamaan tahun lahir dalam rentang waktu 20 tahun dan berada dalam dimensi sosial dan dimensi sejarah yang sama. ${ }^{14}$ Menurut peneliti Kupperschmidt generasi adalah sekelompok individu yang mengidentifikasi kelompoknya berdasarkan kesamaan tahun kelahiran, umur, lokasi, dan kejadian-kejadian dalam kehidupan kelompok individu tersebut yang memiliki pengaruh signifikan dalam fase pertumbuhan mereka. ${ }^{15}$

Istilah Milenial pertama kali dicetuskan oleh William Strauss dan Neil dalam buku Millennials Rising: The Next Great Generation pada tahun 2000. Surya Putra ${ }^{16}$ mengelompokkan pandangan teori perbedaan generasi dari para pakar, dalam tabel 1 di bawah ini sesuai rentan waktu kelahiran.

Tabel 1. Teori perbedaan generasi dari para ahli ${ }^{17}$

\begin{tabular}{|c|c|c|c|c|c|}
\hline $\begin{array}{c}\text { apscott } \\
(1988)\end{array}$ & - & $\begin{array}{c}\text { Baby Boom } \\
\text { Generation } \\
(1946-1964)\end{array}$ & $\begin{array}{c}\text { Generation X } \\
(1965-1975)\end{array}$ & $\begin{array}{c}\text { Digital } \\
\text { Generation } \\
(1976-2000)\end{array}$ & \\
\hline Howe \& & Silent & Boom & 13 th & Millineal & - \\
Strauss & Generation & Generation & Generation & Generation & \\
$(2000)$ & $(1925-1943)$ & $(1943-1960)$ & $(1961-1981)$ & $(1982-2000)$ & \\
\hline Zemke et al & Veterans & Baby & Gen-Xers & Nexters & - \\
$(2000)$ & $(1922-1943)$ & Boomers & $(1960-1980)$ & $(1980-2000)$ & \\
& & $(1943-1960)$ & & & \\
\hline
\end{tabular}

${ }^{14}$ Statistic Gender Tematik: Profil Generasi Milenial Indonesia (Kementrian Pemberdayaan Perempuan Dan Perlindungan Anak Dengan Badan Pusat Statistik, 2018), 13.

15 Ibid.

16 Ibid.

17 Ibid. 
CARAKA: Jurnal Teologi Biblika dan Praktika, Vol. 2, No. 2, November 2021

\begin{tabular}{|c|c|c|c|c|c|}
\hline $\begin{array}{c}\text { Lancaster \& } \\
\text { Stillman } \\
(2000)\end{array}$ & $\begin{array}{l}\text { Traditionalist } \\
(1900-1945)\end{array}$ & $\begin{array}{c}\text { Baby } \\
\text { Boomers } \\
(1946-1964)\end{array}$ & $\begin{array}{c}\text { Generation } \\
\text { Xers }\end{array}$ & Generation Y & - \\
\hline $\begin{array}{c}\text { Martin \& } \\
\text { Tulgan } \\
\text { (2002) }\end{array}$ & $\begin{array}{c}\text { Silent } \\
\text { Generation } \\
(1925-1942)\end{array}$ & $\begin{array}{c}\text { Baby } \\
\text { Boomers } \\
(1946-1964)\end{array}$ & $\begin{array}{c}\text { Generations } \\
\text { X (1965- } \\
1977)\end{array}$ & $\begin{array}{c}\text { Millinials } \\
(9181-1999)\end{array}$ & - \\
\hline $\begin{array}{c}\text { Oblinger \& } \\
\text { Oblinger } \\
(2005)\end{array}$ & $\begin{array}{l}\text { Maataures } \\
(<1946)\end{array}$ & $\begin{array}{c}\text { Baby } \\
\text { Boomers } \\
(1947-1964)\end{array}$ & $\begin{array}{c}\text { Generation } \\
\text { Xers (1965- } \\
1980)\end{array}$ & $\begin{array}{c}\text { Gen- } \\
\text { Y/NetGen } \\
(1981-1995)\end{array}$ & $\begin{array}{c}\text { Post } \\
\text { Millinials } \\
\text { (1955- } \\
\text { present) }\end{array}$ \\
\hline
\end{tabular}

Working With Generations X And Y In Generation Z Period: Management Of Different Generations In Business Life (Sezin Baysal Berkup, Gediz University, İzmir, Turkey, 2014) mengatakan bahwa generasi milenial adalah generasi mereka yang lahir pada tahun 1980 sampai dengan tahun 2001. Benesik, Csikos, dan Juhes, seiring menurunnya generasi baby boom, mereka menambahkan satu generasi lagi yang mulai meramaikan angkatan kerja dalam kelompok generasi yaitu generasi Z. Mereka mengidentifikasi generasi milenial adalah mereka yang lahir antara tahun 1980-1995. Seperti yang tertera dalam tabel 2 di bawah ini.

Tabel 2. Teori perbedaan generasi Veteran-Alfa ${ }^{18}$

\begin{tabular}{|c|c|}
\hline Tahun kelahiran & Nama Generasi \\
\hline $1925-1946$ & Veteran Generation \\
\hline $1946-1960$ & Baby boom Generation \\
\hline $1960-1980$ & X Generation \\
\hline $1980-1995$ & Y Generation \\
\hline $1995-2010$ & Z Generation \\
\hline
\end{tabular}

${ }^{18}$ Ibid. 


\section{$2010+$}

Alfa Generation

United States Census Bureau, mengatakan generasi milenial adalah mereka yang lahir pada tahun 1982 sampai taahun 2000. Sedangkan The Millennial Generation Research Review NCF berpendapat bahwa generasi milenial lahir pada tahun 1980 sampai pada tahun 1999, seperti pada tabel 3 di bawa ini.

Tabel 3. Teori perbedaan generasi menurut jenis dan tahun lahir ${ }^{19}$

\begin{tabular}{|c|c|}
\hline Jenis Generasi & Lahir \\
\hline GI Generation & $1901-1924$ \\
\hline Silent Generation & $1925-1946$ \\
\hline Baby Boom Generation & $1946-1964$ \\
\hline Generation X & $1965-1979$ \\
\hline Millennial Generation & $1980-1999$ \\
\hline Generation Z & $2000-$ \\
\hline
\end{tabular}

Selain itu Statistic gender tematik memaparkan beberapa ahli dalam negeri yang memberi tanggapan mengenai tahun lahir generasi milenial, diantaranya Hasanuddin Ali dan Lilik Purwandi beranggpan bahwa generasi milenial adalah mereka yang lahir pada tahun 1981 sampai pada tahun 2000, dalam buku Milenial Nusantara. Para peneliti lainnya menggunakan tahun lahir mulai dari 1980-an sampai pada tahun 2000-an untuk menetapkan tahun lahir generasi milenial ini. Berdasarkan pandangan dari beberapa ahli ini, maka secara garis besar penentuan tahun lahir generasi milenial adalah mereka yang lahir pada tahun 1980 sampai dengan tahun 2000. Dan hal ini selanjutnya menjadi acuan bagi penulis dalam tulisan ini.

\section{Karakteristik Generasi Milenial}

Karena lahir pada era kebangkitan teknologi dan modernisasi, maka generasi milenial terkena dampak digitalisasi, dimanjakan dengan gelombang teknologi informasi dan sistem informasi yang pesat, terkena dampak revolusi berita sehingga membuat generasi milenial memiliki terterlibatan yang intens pada informasi melalui media sosial dan akses internet yang

${ }^{19}$ Ibid.

131 | Copyright@ 2021, CARAKA, ISSN 2722-1407 (Cetak), 2722-1393 (Online) 
mudah terjangkau. ${ }^{20}$ Generasi milenial mudah up date semua informasi di dunia, mereka menjadi dominan di dunia maya; fashion, lifestyle, makanan, film, serial tivi, tokoh-tokoh imajiner, produk-produk branded, barang-barang elektronik, dan segala informasi di dunia akan mempengaruhi respons mereka seperti cara ekspresi, tutur kata, visualisasi. ${ }^{21}$ Cara kerja generasi milenia, lebih suka bebas, independen dan resilien. Karena dibesarkang dengan kemajuan teknologi, pembekalan mengenai kerja dan tindakan yang kreatif, inofatif, produktif dimiliki oleh generasi ini. Generasi milenial juga memiliki karakteristik komunikasi umum, fanatik akan media social, dipengaruhi oleh perkembaangan teknologi, dan tertarik akan politik dan ekonomi, memiliki antusias yang tinggi terhadap perubahan lingkungan yang terjadi disekitarnya.

\section{Generasi Milenial Perkotaan dan Pedesaan}

Generasi milenial perkotaan dipengaruhi oleh pola pikir penduduk di perkotaan. Tiga ciri utama generasi milenial perkotaaan, yaitu confidence adalah orang-orang yang sangat percaya diri, berani menyumbangkan pemikiraan dan memaparkan pendapat. Kedua, creatice adalah orang-orang yang berpikir out of the box, memiliki ide-ide yang cemerlang dan gagasan yang baik, serta mampu memaparkaan ide dan gagasan itu dengan sangat baik. Ketiga, connected adalah orang-orang yang pintar berkomunikasi dalam komunitas, organisasi, dan public. Juga generasi milenial perkotaan sangat aktif di media social dan internet. ${ }^{22}$

Generasi milenial pedesaan lebih dominan kepada pekerjaan, dimana mereka terlibat langsung dalam praktek kerja lapangan apa pun itu. Hal ini dilakukan untuk mencukupi kebutuhan hidup sehari-hari. Sosial media bukan aktivitas yang terus menerus dilakukan karena bagi generasi milenial di pedesaan social media hanya sekedar pengisi waktu luang. Generasi milenial pedesaaan, tidak terlalu menitik beratkan kehidupan mereka akan ketergantungan media sosial, sebagian besar karena masalah ekonomi, bahkan merk gadgetpun tidak menjadi prioritas, mereka juga tidak terlalu antusias untuk menanggapi isu-isu yang ada dimedia sosial. ${ }^{23}$

\section{Tantangan Pembinaan Warga Gereja bagi Generasi Milenial}

\footnotetext{
${ }^{20}$ Yan O Kalampung Jeane Marie Tulung, Achmad Syahid, Yanice Janis, Generasi Milenial Diskursus Teologi, Pendidikan, Dinamika Psikologis Dan Kelekatan Pada Agama Di Era Banjir Informasi (Depok: Rajawali Pers Divisi Buku Perguruan Tinggi Pt Rajagrafindo Persada, 2019), 19.

${ }^{21}$ Akrur Barua Patricia Buckley, Peter Viechnicki, “A New Understanding Of Millennials: Generational Differences Reexamined," Deloitte University Press, (2015): 1.

${ }^{22}$ Statistic Gender Tematik: Profil Generasi Milenial Indonesia, 22.

${ }^{23}$ Ibid, 23.
} 
Generasi milenial atau generasi Y adalah generasi yang lahir pada tahun 1980-an sampai 1990-an. Generasi ini generasi muda yang usianya 21-38 tahun (di tahun 2021). Generasi milenial sangat dipengaruhi dengan perkembangan teknologi digital. Milenial lebih memusatkan perhatian kepada dunia digital. Sifat ke-aku-an sangat menonjol dikalangan milenial, lebih mengedepankan filosofi "aku online maka aku ada". Titaley mengatakan bahwa generasi milenial sementara meninggalkan agama-agama institusional (termasuk gereja) dengan kecepatan tinggi. 39\% generasi milenial memberikan pengakuan bahwa tidak memiliki identitas keagamaan (umur 18-29), dan 60\% milenial memberi pengakuan bahwa tidak memiliki kepercayaaan lagi terhadap ajaran yang diajarkan agama masa kanak-kanak mereka. ${ }^{24}$ Titaley mengutip kutipan Maldonado mengatakan milenial memiliki warna dan karakter tersendiri dalam religiusitas, yang artinya pemimpin agama pada masa kini (terlebih gereja) harus siap menerima kenyataan perubahan itu. Ini adalah kenyataan yang perlu diterima oleh agama bahwa agama sedang berhadapan dengan suatu generaasi yang jauh berbeda dengaan generasi sebelum-sebelumnya. ${ }^{25}$

Perlu diketahui bahwa agama-agama dunia termasuk gereja sendiri terlahir dari konteks agrarian societies, sementara dunia modern ini sejak abad 20 telah mengalami perubahan yang sangat pesat dalam ilmu pengetahuan dan teknologi. ${ }^{26}$ Oleh karena itu worldview sudah sangat jauh berbeda sejak awal berdirinya sejarah agama-agama sampai pada peradaban yang modern, sehingga simbol-simbol agrarian societies tidak dapat dihayati lagi dalam dunia kontemporer. Secara umum baik generasi milenial perkotaan maupun generasi milenial pedesaan memiliki pradikma yang sama yaitu pola pikir modern. Peristiwa di perkotaan akan terdengar dan diketahui oleh orang-orang di pedesaaan, begitu juga sebaliknya peristiwa pedesaaan akan terdengar dan diketahui oleh orang-orang perkotaan (ada proses pertukaran informasi). Sehingga yang membedakan generasi milenial perkotaan dan generasi milenial pedesaan bukan sudut pandang tentang modernisasi tetapi lebih tepatnya tentang etika dan moralitas. Dalam hal ini tantangan yang dipaparkan ada dalam jati diri generasi milenial pada umumnya.

\section{Model Pembinaan Warga Gereja bagi Generasi Milenial (Sintesis Kontekstual)}

Model sintesis kontekstual. Merupakan model jalan tengah, dimana model ini menekankan pengalaman masa kini (pengalaman, kebudayaan, lokasi sosial, dan perubahan sosial) termasuk globalisasi dan modernisasi, dan menekankan pengalaman masa lampau yaitu

${ }^{24}$ John Titaley, "Religiositas Generasi Milenial: Tantangan Bagi Kehidupan Beragama Dari Perspektif Kristiani," Rajawali Pers Divisi Buku Perguruan Tinggi Pt Rajagrafindo Persada D E P O K (2019): 34.

25 Ibid.

${ }^{26}$ Karen Amstrong Dalam Parlement Of World Religions Pada Tahun 2003 Di Spanyol, Barcelona. 
kitab suci. ${ }^{27}$ Dalam model sintesis kontekstual juga terdapat pendekatan dialetik. Dimana dalam dialetik terjadi proses interaksi antara teks dengan konteks. Dengan demikian gereja harus menggunakan peran kenabiannya untuk menganalisa, menginterpretasi dan menilai setiap keadaan dalam perkembangan zaman. ${ }^{28}$

Banyak sekali perubahan yang telah terjadi di era modern ini, tentunya perlu pembinaan warga gereja yang relevan untuk mengkontekstualisasikan pengajaran yang akan diberikan kepada generasi milenial, tetapi esensi dasar dari ajaran kekristenan harus tetap menjadi pegangannya dan menjadi acuan dalam proses pembinaan. Karena itu model pendekatan kontekstual ${ }^{29}$ Sintesislah yang cocok digunakan sebagai model pembinaan bagi generasi milenial.

\section{Pentingnya Pembinaan Warga Gereja bagi Generasi Milenial}

Penting bagi gereja untuk mempersiapkan dan membekali para muda-mudi karena mereka adalah penerus di dalam gereja yang akan menggantikan orang-orang tua dan yang akan menjadi dampak bagi dunia kontemporer. Hampir setiap gereja pada umumnya memiliki calon-calon penerus, saat ini yang terdaftar sebagai anggota gereja sebagian besar dari generasi milenial. Oleh karena itu, Ganggel berpendapat bahwa perlunya pembinaan dalam jemaat tujuannya adalah untuk mencetak jemaat-jemaat yang dewasa dalam iman Kristen yang sempurna. ${ }^{30}$ Riniwati mengutip B. S. Sidjabat memberi empat tanggapan perlunya pembinaan dalam jemaat, yaitu:

Pertama, untuk perubahan warga gereja. Perubahan disini adalah perubahan karakter menuju kepada keserupaan dengan Kristus, yang tentunya tidak lepas dari pekerjaan Roh Kudus, karena kita diselamatkan oleh anugerah Allah supaya semakin serupa dengan Yesus. Seperti dalam 1 Yohanes 2:6; 2 Korintus 5:17; Roma 12:1-2. Kedua, warga gereja perlu dibina untuk pengembangan diri. Dalam aspek kehidupan seseorang berkembang dalam artian holistik. Manusia memiliki dimensi individu dan sosial, manusia juga terbagi dalam tiga bagian yaitu kebutuhan jasmani, kebutuhan jiwa, dan kebutuhan roh, semuanya ini menuntut untuk terpenuhi kebutuhannya. Oleh karena itu Pembinaan Warga Gereja perlu menyentuh dan memperkaya aspek pengetahuan, pengertian, perasaan, sikap, minat, relasi, perilaku social, kultural dan kerohanian agar diantaranya tidak terdapat ketidak seimbangan dan kesenjangan, semuanya itu hanya dapat dipenuhi di dalam Yesus Kristus (1 Korintus 3:11; Kolose 2:6-7). Ketiga, warga

27 Jekson Berdame Meily Meiny Wagiu, "Generasi Milenial Diskursus Teologi, Pendidikan, Dinamika Psikologis Dan Kelekatan Pada Agama Di Era Banjir Informasi: Liturgi Kontekstual Berbasis Multikultural Bagi Generasi Milenial Di Iakn Manado," Rajawali Pers Divisi Buku Perguruan Tinggi Pt Rajagrafindo Persada Depok (2019): 92-93.

${ }^{28}$ David Eko Setiawan, Injil Manusia Dan Beradabannya (Jogjakarta: Penerbitan Kbm Indonesia, 2021), 54 .

29 David Eko Setiawan, "Menemukan Sebuah Model Misi Perintisan Jemaat Alkitabiah-Kontekstual Bagi Sebuah Gereja Lokal Baru," Osf (2018): 7.

${ }^{30}$ Kenneth O. Ganggel, Membina Pemimpin Pendidikan Kristen (Malang: Gandum Mas, 1996), 53. 
gereja perlu dibina untuk tugas dan tanggungjawab. Tanggung jawab yang dimiliki terhadap Tuhan, diri sendiri, orang tua, keluarga, gereja, dan masyarakat. Efesus 2:10, karena manusia adalah buatan Allah yang diciptakan dalam Kristus Yesus untuk melakukan perbuatan-perbuatan baik, Titus 2:14, karena jemaat milenial juga telah ditebus dan dikuduskan bagi Yesus Kristus yang adalah milik kepunyaan-Nya, dan yang rajin berbuat baik. Untuk melakukan tugas dan tanggung jawab sebagai seorang Kristen perlu juga melandasinya dengan kebaikan. Keempat, warga gereja perlu dibina untuk menjawab kebutuhan gereja. Gereja diutus ke tengah-tengah dunia adalah untuk menjadi saksi Yesus, menjadi dan membawa kabar baik di tengah-tengah dunia ini dan memberikan berbagai ragam hikmat Allah (Matius 28:19-20; Efesus 3:10; 1 Petrus 2:9-10). ${ }^{31}$

\section{Ciri-ciri dan Sifat Generasi Milenial dalam Gereja}

Generasi milenial sangat beragam dalam gereja, mulai dari orang-orang muda umur 21 tahun sampai umur 38 tahun. Artinya dalam generasi milenial terdapat juga orang-orang dewasa muda. Sekalipun demikian generasi milenial yang kompleks ini sangat memerlukan pembinaan. Oleh sebab itu pemimpin atau pelayan Tuhan yang terlibat dalam pelayanan generasi milenial harus memahami kebutuhan generasi milenial agar pembinaaan yang dilakukan dapat mendarat dengan baik. Adapun ciri-ciri dan sifat dari generasi milenial yang ditemukan di gereja secara umum sebagai berikut:

Pertama, generasi milenial merupakan pribadi-pribadi yang antusias dalam perubahan, dari segi jasmani dan intelektual generasi milenial sedang dalam proses pertumbuhan yang pesat. Dalam tahap ini milenial sedang mengumpulkan pengalaman-pengalaman untuk menjadi bekal. Diantaranya milenial sedang melakukan uji coba dalam setiap perkerjaan yang mereka lakukan. Kedua, generasi milenial ke gereja datang dengan berbagai macam tujuan, seperti: ada yang datang dengan berorientasi kepada tujuan dan harapan, namun ada juga yang datang sekedar rutinitas. Ketiga, setiap individu milenial memiliki keunikannya sendiri, cara belajar, cara bersosial, dan sampai pada cara berekspresi. Salah satu tantangan gereja terhadap generasi milenial yaitu, milenial memiliki antusias belajar jika kegiatan yang dilaksanakan sesuai, menyentuh, dan memperkaya wawasan mereka.

\section{Pelaku Pembinaan Warga Gereja bagi Generasi Milenial}

Pembinaan warga gereja bagi generasi milenial, tentunya diperlukan kelompok ataupun idividu yang mengerti tentang persoalan generasi milenial. Tuntutun utama yang perlu diperhatikan untuk memenuhi kriteria sebagai Pembina generasi milenial (di gereja) harus memiliki pengetahuan yang mendalam akan Firman Tuhan dan ketaataan terhadap iman

31 Riniwati, "Bentuk Dan Strategi Pembinaan Warga Jemaat Dewasa," Prosiding Seminar Nasional Pendidikan Agama Kristen Sekolah Tinggi Teologi Simpson (2016): 3-4. 
kepada Yesus Krsitus, ${ }^{32}$ Tidak cukup bermodalkan pengalaman saja tetapi harus memiliki antusias terhadap perubahan dan perkembangan dunia baik teknologi dan pengetahuan social, produktis, profesional, berjiwa milenial, dan sanggup memberikan teladan yang benar. ${ }^{33}$

Boestam, memaparkan tiga belas karakteristik pemimpin milenial, yaitu: Kesabaran mampu mengendalikan emosi dalam pembinaan terhadap milenial, memiliki daya juang yang tinggi, kasih dan belas kasihan terhadap sesama (humanis), konsisten, memiliki hubungan yang baik dengan Tuhan, lemah lembut, mudah diajar (Teachable) memiliki rasa penundukan, kecakapan memimpin, prioritas nomor satu, harus mempunyai visi yang jelas, memiliki kapasitas atau kemampuan untuk menunjukkan arah kepada pengikutnya dan mampu menggerakkan potensi dalam menggapai sasaran yang telah ditentukan, memiliki kemampuan operasional dan kemampuan konseptual, mempunyai pola pikir yang berorientasi ke masa depan. ${ }^{34}$ juga kejujuran. ${ }^{35}$

\section{Aspek-aspek Pembinaan Warga Gereja bagi Generasi Milenial}

Pertama, aspek pembinaan iman Kristen. Bentuk ini meliputi seluruh pengajaran ketristenan, hal ini untuk mengantisipasi dimana mahasiswa (generasi milenial) sedang meninggalkan agama-agama institusional dengan pesat. ${ }^{36}$ Karena itu generasi milenial perlu ditanamkan kembali rasa beragama yang luhur. Dalam hal ini pengajaran yang diajarkan adalah pengajaran doktrin iman Kristen agar generasi milenial dibekali dan siap untuk menjadi penerus-penerus dalam gereja.

Kedua, aspek pembinaan terhadap media online. Pembinaan terhadap perkembangan teknologi ini perlu untuk dilakukan bagi generasi milenial agar mereka mengerti batasanbatasan dalam penggunaannya, terlebih khusus pada penggunaan media online, yang sekarang ini baik hal-hal negatif dan hal-hal positif telah bercampur-aduk dalam media online. Perlu adanya pengajaran untuk penyaringan semua informasi dari media online.

32 Yonatan Alex Arifianto, "Peran Gembala Menanamkan Nilai Kerukunan Dalam Masyarakat Majemuk," Voice Of Hami, Peran Gembala Menanamkan Nilai Kerukunan Dalam Masyarakat Majemuk 3 (2020): 2 .

33 Talizaro Tafonao, Penerapan Strategi Pengajaran Tuhan Yesus Terhadap Pencapaian Tujuan Pendidikan Agama Kristen, Prosiding Seminar Nasional "Tata Kelola Perguruan Tinggi Kristen Di Indonesia" (Yogjakarta: Di Stt Kad, 2018), 128.

${ }^{34}$ P. Boestam, Smart Christian Leadership (Yogjakarta: Andy, 2013), 49.

${ }^{35}$ Marsi Bombongan Rantesalu, "Karakter Kejujuran Dalam Gereja Masa Kini," Jurnal Ilmu Teologi Dan Pendidikan Agama Kristen 1 (2020): 49-50.

${ }^{36}$ Yan O Kalampung Jeane Marie Tulung, Achmad Syahid, Yanice Janis, Generasi Milenial Diskursus Teologi, Pendidikan, Dinamika Psikologis Dan Kelekatan Pada Agama Di Era Banjir Informasi (Depok: Rajawali Pers Divisi Buku Perguruan Tinggi Pt Rajagrafindo Persada, 2019), 35. 
Ketiga, aspek pembinaan perseorangan (pastoral). Dimana pembinaan ini bertujuan untuk membimbing langsung tiap anggota gereja generasi milenial yang mengalami permasalahan. Pembinaan perseorangan ini membantu generasi milenial untuk mengenal dan mengerti apa yang sedang terjadi dalam diri sendiri, persoalan yang dihadapi, kondisi hidup, dan suasana batinnya. ${ }^{37}$

Keempat, aspek pembinaan terhadap millenials life style. Gaya hidup yang salah dapat membawa permasalahan dalam pergaulan generasi milenial. Kehidupan yang serba menuntut baik dalam pergaulan dan dunia pekerjaan, seringkali membuat generasi milenial mengalami krisis eksistensi, sehingga menimbulkan tidak percayaan diri dalam menghadapi kehidupan. Oleh karena itu pembinaan terhadap millenials life style perlu diperhatikan gereja. Memberi tahu bagaimana seharusnya etika dalam kehidupan zaman ini dan pandangan hidup kekristenan hedonis. ${ }^{38}$

\section{Materi Pembinaan Warga Gereja bagi Generasi Milenial}

Parker J. Palmer, mengatakan bahwa isi Alkitab adalah materi pembelajaran. Alkitab adalah yang ingin diketahui sedangkan manusia adalah yang ingin mengetahui, oleh karena itu jika keduanya memiliki interaksi maka kebenaran akan ditemukan. Hal ini memerlukan ketaatan, sehingga setiap saat murid belajar kebenaran tentang Kristus dan kasih-Nya melalui guru dalam proses pembelajaran. ${ }^{39}$ Diperlukan juga materi-materi tambahan untuk seminar pelatihan talenta.

Dalam pembinaan warga gereja bagi generasi milenial terbagi dalam beberapa kelompok. Pertama, petobat baru. Pengajaran satu arah adalah strategi pembinaan bagi petobat baru, materi yang diberikan tentang ajaran dasar iman Kristen, dalam injil Yohanes pasal satu yang membahas tentang ketuhanan Yesus Kristus. Kedua, Pembinaan dasar. Diskusi Alkitab adalah strategi pembinaan bagi pembinaan dasar. Materi yang diberikan tentang trinitas, dan soteriologi. Ketiga, Pembinaan lanjutan. Diskusi Alkitab adalah strategi pembinaan bagi pembinaan lanjutan. Materi yang diberikan adalah pembahasan dalam kitab Roma.

\section{Strategi dalam Program Pembinaan Warga Gereja bagi Generasi Milenial}

Jerry Subblesfild, memaparkan empat program penting. Program untuk memahami Alkitab, pelatihan-pelatihan pemuridan, keterlibatan dalam misi, pendidikan keluarga dan pelayanan musik. Sedangkan, Gangel dan Wilhoit mengusulkan bentuk-bentuk pembinaan

${ }^{38}$ Ibid., 280.

39 Stanley Tjahjadi, Guruan Spiritual: Suatu Pendekatan Baru Bagi Guruan Kristiani (Jakarta: Bpk Gunung Mulia, 2002), 279-281. 
meliputi beberapa hal, yaitu: pelayanan kepada orang tua, pendidikan keluarga sekolah minggu dewasa, pembinaan dan pemuridan. Seminar dan lokakarya. ${ }^{40}$ Perlu adanya penambahan dan penyusunan yang tersistematis dalam program pembinaan warga gereja bagi generasi milenial seperti berikut:

Pertama, materi untuk pembinaan generasi milenial yaitu; Pemahaman iman secara mendasar, (bahan Alkitab dan buku gereja), mempelajari secara khusus tentang Kristologi dalam injil Yohanes pasal satu, sebagai bahan ajar, dalam permasalahan dan krisis sebagai orang Kristen perlu mempelajari tentang pertumbuhan iman, pertumbuhan iman akan berjalan jika ada bantuan dari Roh Kudus. Karna itu perlu mempelajari Roh Kudus, oknum ketiga dari trinitas, sosok Yesus adalah teladan hidup, belajar tentang sejarah gereja, pengasahan talenta, dan pembekalan dalam bisnis dan pekerjaan.

Kedua, program untuk pembinaan generasi milenial, yaitu; Seminar, KKR milenial, Retreat, Nobar (nonton bareng), Ruangan khusus milenial (studio, lapangan olaraga, perpustakaan), Diskusi Alkitab, dan Event puncak.

\section{Langkah-langkah mencapai program}

Untuk melaksanakan program pemuridan yang sudah ditentukan, berikut langkahlangkah yang tepat untuk menarik minat generasi milenial menghadirinya. Pertama, strategi program seminar. Dapat dilaksanakan di Gereja atau aula, dekorasi disesuaikan dengan tema seminar. Contoh tema "Yesus dan Milenial." Dapat berdurasi selama enam jam dengan beberapa sesi (brak time), dilakukan selama sehari. Bahan dan materi membahas tentang salah satu materi yang ada di atas (dibungkus dengan bahasa milenial) dan ditutup dengan ajakan untuk menjadi laskar Kristus.

Kedua, strategi program KKR milenial. Dapat dilaksanakan di lapangan terbuka dan aula, dekorasi disesuaikan dengan tema KKR. Contoh tema "Millenials life style". Bisa berdurasi dua jam, bisa dilakukan selama lima hari sampai tujuh hari. Bahan dan materi membahas tentang Roh Kudus, dan penutupan hari puncak dengan panggilan altar.

Ketiga, strategi program retreat. Dapat dilaksanakan di pantai bumi perkemahan, dekorasi disesuaikan dengan tema. Contoh tema "Gereja dan Alam." Hari retreat selama dua hari, dua jam dalam sehari digunakan untuk pembahasan materi dalam bentuk diskusi (selebihnya acara-acara milenial). Bahan dan materi, membahas tentang salah satu materi yang

${ }^{40}$ Riniwati, "Bentuk Dan Strategi Pembinaan Warga Jemaat Dewasa," 4-5. 
ada di atas (dibungkus dengan bahasa milenial), dalam bentuk diskusi dan ditutup dengan ajakan mencintai lingkungan hidup.

Keempat, strategi program nobar (nonton bareng). Dapat dilaksanakan di aula gereja dan di rumah jemaat, tujuan pelaksanaan nobar adalah untuk mempererat hubungan kebersamaan. Film yang ditonton adalah film-film inspirasi dan motivasi untuk generasi milenial. Nobar dapat dibungkus sedemikian rupa untuk untuk kepentingan bersama, dan diakhiri dengan Fellowship.

Kelima, penyediaan tempat. Penyediaan tempat atau sarana tujuannya untuk memperlengkapi generasi milenial dalam mempertajam talenta dan melatih skill dalam pekerjaan. Oleh karena itu gereja menyediakan sarana dan prasarana dalam hal ini adalah tempat seperti lapangan olahraga, studio rekaman, perpustakaan, dan ruang seni untuk kreativitas.

Keenam, program diskusi Alkitab. Dapat dilaksanakan di gereja, rumah, dan café, durasi dapat dilakukan selama dua jam dalam waktu sekali seminggu. Tujuannya untuk memperlengkapi generasi milenial dalam pemahaman yang mendalam tentang Firman Tuhan.

Ketujuh, event puncak. Contoh event puncak: melakukan Study Tour, mengunjungi situs-situs sejarah dan budaya untuk memperlengkapi generasi milenial untuk menjadi orang Kristen yang nasionalis dan berbudaya, bisa juga melakukan pelayanan amal ke panti-panti, dan melakukan pelayanan “Tukar Mimbar” antar gereja, untuk membangun kebersamaan antar jemaat terkhususnya untuk generasi milenial.

Dalam tujuh program yang di paparkan ini akan menjawab setiap permasalahan dalam setiap aspek yang ada di atas. Ada beberapa program yang setiap minggu perlu dilakukan seperti Pendalaman Alkitab dan Nobar. Semua program di atas merupakan strategi pembinaan sintesis yang kontekstual, tentunya berlaku bagi semua umur dikalangan milenial. Perubahan yang diharapkan dalam model pembinaan sintesis kontekstual bagiwarga gereja generasi milenial, yaitu:

Pertama, perubahan dalam segi kerohanian. Melalui pembinaan lewat strategi dan program di atas diharapkan ada perubahan yang terjadi bagi generasi milenial secara rohani. Tentunya perubahan ini tidak terjadi secara otomatis, membutuhkan kerjasama yang sinergis dari dua pihak yaitu pelaku pembina dan anggota jemaat generasi milenial. Tanda perubahan rohani adalah menunjukan buah roh dalam kehidupan sehari-hari (Gal. 2:20; 1 Kor. 2:14). 
Kedua, perubahan akal budi. Melalui pembinaan lewat strategi dan program di atas diharapkan ada perubahan yang terjadi bagi generasi milenial dalam akal budi. Dengan perubahan akal budi anggota jemaat generasi milenial akan dapat membedakan mana yang benar dan baik, dan yang berkenan kepada Allah (Rom. 12:2), agar setiap hal dapat diputuskan dan dipertimbangkan matang-matang dengan penuh hikmat dan kebijaksanaan (Amsl. 3:13).

Ketiga, perubahan tingkah laku. Melalui pembinaan lewat strategi dan program di atas diharapkan ada perubahan yang terjadi bagi generasi milenial terhadap tingkah laku. Seperti yang terdapat dalam 2 Timotius 3:16 dikatakan bahwa firman Tuhan memiliki manfaat yaitu: untuk mengajar, menyatakan kesalahan, memperbaiki kelakuan dan untuk mendidik orang dalam kebenaran. Oleh karena itu firman Tuhan sanggup mengubah tingkalaku dari setiap orang yang terbuka untuk dibina (Amsl. 3:3).

Keempat, memiliki kesadaran sebagai anak-anak Allah. Warga gereja generasi milenial perlu menyadari bahwa mereka dilahirkan sebagai anak-anak Allah (Rom. 8:16-17) yang memiliki tugas untuk menjadi garam dan terang dunia (Mat. 5:13-14).

\section{KESIMPULAN}

Model pembinaan terhadap generasi milenial di era globalisasi ini sangatlah penting. Generasi milenial adalah orang muda dan orang tua muda yang awam karena dari itu perlu diperhatikan gereja. Mereka memiliki kelemahan dan ketidak mampuan dalam mengatasi permasalahan dewasa ini, menghadapi pertanyaan-pertanyaan dari para penganut paham sesat yang bermunculan sehingga ada banyak dari generasi milenial yang akhirnya terjerumus dalam pergaulan dunia. Banyak didapati bahwa generasi mileniallah yang mengambil bagian paling banyak sebagai pelaku yang tidak mengakui adanya Tuhan, juga mengambil keputusan untuk memegang keyakinan yang lain. Hal-hal seperti ini terjadi dikarenakan kurangnya pembekalan dan didikan yang tepat mengenai kebutuhan rohani, sehingga generasi milenial pun mencari tahu dan mendapatkan pemahaman yang keliru dan ketersesatan. Dengan mempertimbangkan hal tersebut, maka gereja perlu mengambil sikap yang serius dimana gereja perlu membuat model pembinaan yang tepat bagi generasi milenial guna menjawab semua kebutuhan generasi milenial di era globalisasi. Model yang diharapkan ialah model yang relevan dan tentunya kontekstual dengan budaya dari generasi milenial. 


\section{DAFTAR PUSTAKA}

Arifianto, Yonatan Alex. "Peran Gembala Menanamkan Nilai Kerukunan Dalam Masyarakat Majemuk." Voice Of Hami, Peran Gembala Menanamkan Nilai Kerukunan Dalam Masyarakat Majemuk 3 (2020).

Barus, Armand. "Pemuridan Sebagai Misi Gereja Studi Matius 28:16-20.” Jurnal Amanat Agung (2013).

Boestam, P. Smart Christian Leadership. Yogjakarta: Andy, 2013.

Bulo, Yw Ardhana Septiani. "Kepemimpinan Transformasional Dalam Gereja Bagi Pelayanan Generasi Muda (Y Dan Z).” Duta Wacaana (N.D.).

Diana, Ruat. "Permasalahan Pembinaan Warga Gereja Di Kewari." Evangelikal: Jurnal Teologi Injili Dan Pembinaan Warga Jemaat 2, No. 1 (2018).

Eka Diah Kartiningrum, Mkes. Panduan Penyusunan Studi Literatur. Mojokerto: Lembaga Penelitian Dan Pengabdian Masyarakat Politeknik Kesehatan Majapahit Mojokerto, 2015.

Ganggel, Kenneth O. Membina Pemimpin Pendidikan Kristen. Malang: Gandum Mas, 1996.

Jeane Marie Tulung, Achmad Syahid, Yanice Janis, Yan O Kalampung. Generasi Milenial Diskursus Teologi, Pendidikan, Dinamika Psikologis Dan Kelekatan Pada Agama Di Era Banjir Informasi. Depok: Rajawali Pers Divisi Buku Perguruan Tinggi Pt Rajagrafindo Persada, 2019.

. Generasi Milenial Diskursus Teologi, Pendidikan, Dinamika Psikologis Dan Kelekatan Pada Agama Di Era Banjir Informasi. Depok: Rajawali Pers Divisi Buku Perguruan Tinggi Pt Rajagrafindo Persada, 2019.

Kartono, Kartini. Pengantar Metodologi Research Sosial. Bandung: Alumni Bandung, 1980. Marsi Bombongan Rantesalu. "Karakter Kejujuran Dalam Gereja Masa Kini." Jurnal Ilmu Teologi Dan Pendidikan Agama Kristen 1 (2020).

Meily Meiny Wagiu, Jekson Berdame. "Generasi Milenial Diskursus Teologi, Pendidikan, Dinamika Psikologis Dan Kelekatan Pada Agama Di Era Banjir Informasi: Liturgi Kontekstual Berbasis Multikultural Bagi Generasi Milenial Di Iakn Manado." Rajawali Pers Divisi Buku Perguruan Tinggi Pt Rajagrafindo Persada D E P O K (2019).

Nggebu, Sostenis. "Pemuridan Model Epafras Sebagai Upaya Pendewasaan Iman Bagi Warga Gereja." Jurnal Teologi Kristen, H Sekolah Tinggi Alkitab Tiranus 3 (2013): 1.

Patricia Buckley, Peter Viechnicki, Akrur Barua. "A New Understanding Of Millennials: Gen_Erational Differences Reexamined." Deloitte University Press, (2015).

Riniwati. "Bentuk Dan Strategi Pembinaan Warga Jemaat Dewasa."

Prosiding Seminar Nasional Pendidikan Agama Kristen Sekolah Tinggi Teologi Simpson (2016).

Selan, Ruth F. Pedoman Pembinaan Warga Jemaat. Bandung: Kalam Hidup, 2000.

Setiawan, David Eko. Injil Manusia Dan Beradabannya. Jogjakarta: Penerbitan Kbm Indonesia, 2021.

- "Menemukan Sebuah Model Misi Perintisan Jemaat Alkitabiah-Kontekstual Bagi Sebuah Gereja Lokal Baru." Osf (2018).

- "Ritus Pencurahan Darah Korban Binatang : Perjumpaan Injil Dengan Tradisi Manengeh Di Suku Dayak Bumate." Caraka, Jurnal Teologi Bliblika Dan Praktika 2 (2021): 1.

Sidjabat, B.S. Pendewasaan Manusia Dewasa. Bandung: Kalam Hidup, 2014.

Susanto, S. "Strategi Pembinaan Warga Jemaat Dalam Meningkatkan Kehidupan Jemaat (Studi Kasus Di Gkii Tandang).” In Prosiding Seminar Nasional Pendidikan Agama Kristen Dan Call For Papers, 2016. 
Tafonao, Talizaro. Penerapan Strategi Pengajaran Tuhan Yesus Terhadap Pencapaian Tujuan Pendidikan Agama Kristen. Prosiding Seminar Nasional "Tata Kelola

Perguruan Tinggi Kristen Di Indonesia.” Yogjakarta: Di Stt Kad, 2018.

Tari, Ezra, Marulak Pasaribu, Muner Daliman, Dan Paulus T. Wibowo. "Kajian Biblika Tentang Motivasi Yudas Iskariot Mengikut Yesus Berdasarkan Injil Sinoptik Dan Relevansinya Bagi Generasi Milenial.” Osf (2019).

Thobias, Apriati W. S. "Pembentukan Karakter Pemimpin Kristen Yang Unggul Di Era Milenial." Kharisma: Jurnal Ilmiah Teologi Vol. 1, No (2020).

Titaley, John. "Religiositas Generasi Milenial: Tantangan Bagi

Kehidupan Beragama Dari Perspektif Kristiani." Rajawali Pers Divisi Buku Perguruan Tinggi Pt Rajagrafindo Persada D E P O K (2019).

Tjahjadi, Stanley. Guruan Spiritual: Suatu Pendekatan Baru Bagi Guruan Kristiani. Jakarta: Bpk Gunung Mulia, 2002.

Statistic Gender Tematik: Profil Generasi Milenial Indonesia. Kementrian Pemberdayaan Perempuan Dan Perlindungan Anak Dengan Badan Pusat Statistik, 2018. 